there, so that it appeared essential to look into the state of the Swiss glacierization afresh. On the initiative, therefore, of the writer, with the helpful and indispensable assistance of the Service Topographique Fédéral, the Commission Helvétique des Glaciers carried out a planimetric survey of all the ice-covered areas shown on the new map. This very detailed work was carried out with great care by Herr W. Büla.

These areas, 72 in number, were distributed over 34 sheets of the map. As the surveys were spread over many years they naturally refer to varying dates, but in the main they were carried out during a time lapse of about twelve years, namely from 1927 to $194^{\circ}$. In order to determine with accuracy the total variation in an area surveyed over such a prolonged period it would, of course, be necessary to take into account the exact time of the initial and the final surveys. But to obtain a comprehensive picture of the extent of the ice in Switzerland, especially in view of the long lapse of time between the making of the two maps (1877 to 1932 ), this degree of precision was not absolutely necessary; indeed the mere comparison of the total glacierized areas of former times and the present is, of itself, of great value to glaciology and world climatology. For this reason we have considered it opportune to give a total figure for the variation without waiting for the final details. Jegerlehner gave as his computation of the total glacierized area $1853 \mathrm{~km} .^{2}$. In $193^{2}$ it stood at $\mathrm{I}_{3} 84 \mathrm{~km} .^{2}$, a reduction of $469 \mathrm{~km} .^{2}$ (25 per cent) - a little less than the area of the Lake of Geneva, or about 3.3 per cent of the area of the whole country.

It should be noted that these computations refer to the glaciers seen as horizontal areas.

\title{
THE STABILITY OF ICE-DAMMED LAKES AND OTHER WATER-FILLED HOLES IN GLACIERS
}

\author{
By J. W. GLen \\ (Cavendish Laboratory, Cambridge)
}

\begin{abstract}
ABSTRACr. It is well known that an empty hole in a glacier will fill in if it is more than some $\mathbf{1} 5$ to $20 \mathrm{~m}$. deep, due to the rapid variation of strain rate with shear stress. It is pointed out that a water-filled hole or lake will tend to enlarge itself by the same mechanism, if it is more than 150 to $200 \mathrm{~m}$. deep. This phenomenon is believed to be responsible for the periodical and complete emptying of some glacier lakes, such as has been reported for the Tulsequah Lake in British Columbia, and Graenalón and Grímsvötn in Iceland.

Zusammenfassung. Es ist wohlbekannt, dass sich ein leeres, mehr als $15-20 \mathrm{~m}$. tiefes Loch in einem Gletscher von selbst schliesst; dies ist darauf zurückzuführen, dass die Deformationsgeschwindigkeit des Eises mit der Scherspannung sehr rasch ansteigt. Es wird gezeigt, dass sich ein mit Wasser gefülltes, mehr als $150-200 \mathrm{~m}$. tiefes Loch auf Grund desselben Mechanismus von selbst vergrössert. Dieses Phenomän erklärt wohl die periodische und vollständige Leerung gewisser Gletscherseen, wie z.B. des Tulsequah Lake in Britisch Kolumbien, und des Graenalón und Grimsvötn in Island.
\end{abstract}

\section{THEORY}

Recent experiments on the mechanical properties of ice ${ }^{1}$ have shown that, whenever ice is subjected to a shear stress greater than about one bar, flow takes place at a rate which increases rapidly with the stress. An example of this is the filling up of crevasses and bore holes in glaciers; for when a vertical wall of ice is more than some $20 \mathrm{~m}$. high, the ice at the surface of the wall near the bottom is subjected to a vertical compressive stress of about 2 bars in addition to atmospheric pressure, while the horizontal component of the stress in a direction perpendicular to the wall can only be atmospheric. By the usual methods of stress analysis, this implies that there must be a shear stress of about one bar on planes at 45 degrees to the horizontal, and this will cause the ice to flow and the hole to fill in. This explains why crevasses of much greater depth than $20 \mathrm{~m}$. are rare in a temperate glacier. 
For the case of a circular hole Nye ${ }^{2}$ has recently made a more accurate calculation. This shows that the rate of contraction $s$ is connected with the pressure of overlying ice $p$ by the relation

$$
s=(p / n A)^{n}
$$

where $A$ and $n$ are constants from the relation between the applied shear stress $\tau$ and the tensor shear strain rate $\dot{\gamma}$

$$
\dot{\gamma}=(\tau / A)^{n}
$$

The existence of this effect is comparatively well known and appreciated, but the equivalent effect in water-filled holes or in the ice cliffs of glacier-dammed lakes does not seem to have been realized.

If a vertical hole in a glacier contains water, the hydrostatic pressure of the water at a depth $z_{w}$ below the water surface will be $\rho_{w} g z_{w}$ where $\rho_{w}$ is the density of water (approximately unity) and $g$ is the acceleration due to gravity; and this hydrostatic pressure must be the normal stress acting on the ice wall. The vertical compressive stress component acting on the ice at this point will be $\rho_{i} g z_{i}$ where $z_{i}$ is the depth below the ice surface and $\rho_{i}$ the density of ice. If the water fills the hole so that the ice and water surfaces are at the same level (i.e. $z_{w}=z_{i}$ ), the hydrostatic pressure in the water, and hence one horizontal stress component, will be greater than the vertical compressive stress component by an amount $\Delta p=\left(\rho_{w}-\rho_{i}\right) g z$. The situation is thus analogous to the one considered above but with the sign reversed-the horizontal compression is now greater than the vertical-and there will again be shear stresses of order $\Delta p / 2$ on planes at 45 degrees to the horizontal; if these are great enough to cause flow, the hole will enlarge. For example, if $\Delta p / 2=\mathrm{I}$ bar, a water-filled hole will enlarge at the same rate as an empty hole some $20 \mathrm{~m}$. deep will fill up. This will occur at a depth $z$ below the ice and water surface given by $\left(\rho_{w}-\rho_{i}\right) g z=2$ bars, or $z=200 \mathrm{~m}$. This may well be the mechanism by which melt-water streams find their way to the bed of a deep glacier.

\section{Application: The Tulsequah Lake}

Perhaps the most interesting application of this theory is the explanation it offers of the emptying of glacier-dammed lakes. In certain parts of the world there exist quite large lakes which are dammed by glaciers, and it is certain that during the various stages of the Pleistocene epoch many others have occurred. Some of these lakes, for example the Tulsequah Lake in British Columbia ${ }^{3,4}$ empty from time to time, releasing a vast quantity of water to their outflow streams, which often causes catastrophic flooding in the valley below. In the case of the Tulsequah Lake, this water is known to emerge from a tunnel in the glacier snout, and Kerr ${ }^{3}$ has reported that, immediately after an outflow, the lake is completely empty. The usual theory of this phenomenon 4 is that the water builds up until its surface level reaches that of the glacier, when it spills over and the escaping water cuts a channel in the ice and thus gives a catastrophic emptying. It is difficult to see, however, why this should completely empty the lake, and it seems more likely that the level of the water rises until the pressure at the lowest point of the lake exceeds the corresponding ice pressure sufficiently for ice flow to occur. Although, at first, the water will tend to spread equally in all directions along the bed, the enlargement of the lake under the ice in the downhill direction gives an increased pressure there relative to the other points, and thus the lake will dig itself a tunnel under the glacier until it either links up with a subglacial stream already present or emerges at the snout. In either case a catastrophic emptying will occur and the lake will be left completely empty. After emptying, the channel, being now air filled, will quickly close up again to restart the cycle. The Tulsequah Lake has a depth of about ${ }_{15} 0 \mathrm{~m}$., so that this process is quite possible, while the appearance of the newly drained lake apparently points strongly to subglacial drainage. Indeed, Kerr ${ }^{3}$ was forced to postulate its existence, though he seems to have imagined it as taking place through a pre-existing rock passage which is always open, but gets blocked by icebergs at the lake end. 


\section{Graenalón and Grímsvötn}

Another theory has been proposed by Thorarinsson 5 to account for the drainage of icedammed lakes in Iceland. He supposed that the water rises until it is nine-tenths of the height of the ice barrier, after which it can raise the barrier and escape underneath. He applied this theory to all cases of drainage of glacial lakes, whether they were comparatively shallow or, as in the case of Graenalón and Vatnsdalur, over $100 \mathrm{~m}$. deep. Thorarinsson has also applied his theory to the case of Grímsvötn, ${ }^{6}$ a large lake in the middle of Vatnajökull which also empties periodically, the emptying being accompanied by volcanic tremors. He has shown that the outflow is not a result of the volcanic eruption, but rather the reverse, since the peak of the outflow precedes the tremors. He suggested that, in this case, the large heat flow through the earth below Grímsvötn melts a lake, which rises until it can lift the barrier and escape, the consequent drop in pressure allowing the eruption to occur. As evidence for this he compares the drainage discharge patterns of Grimsvötn and Graenalón. In both cases the discharge slowly builds to a maximum and then suddenly stops. This is just the form to be expected if a tunnel is being enlarged by the water pressure during outflow, but is hardly to be expected if the water has simply lifted the ice and descended. This latter case should give a steady, rather than a catastrophic outflow, as the flow would stop as soon as the water level fell below nine-tenths of the barrier height, and restart as soon as more water arrived.

In order for the water to lift the ice from the bed when its depth is nine-tenths of the barrier height there must be no adhesion between the ice and the bed. If, as seems more likely, we assume that the ice is frozen on to the underlying rock, then a greater depth would be needed, and the condition for flow of ice in the manner described above might well be reached first. It is perhaps significant that both Graenalón and Grímsvötn are about $15^{\circ-200} \mathrm{~m}$. deep, the value expected on the plastic flow theory. It would be interesting to see whether lakes with a smaller barrier height show water outflow curves of the same type as the deeper lakes, and whether they empty completely.

In conclusion, I would like to point out that this enlarging process is bound to occur wherever the depth of water on an ice face is sufficiently great, and that this effect ought to be taken into account in any cases where water-filled holes of more than $100 \mathrm{~m}$. depth occur, such as bore holes, glacier mills and glacier streams. This fact can be of great importance in the hydrology of glaciers.

MS. received 22 September 1953

\section{R E F E R E N C E S}

1. Glen, J. W. Experiments on the deformation of ice. Fournal of Glaciology, Vol. 2, No. 12, 1952, p. I1 I-14. Rate of flow of polycrystalline ice. Nature, Vol. 172, No. 4381, 1953, p. 721-22.

2. Nye, J. F. The flow law of ice from measurements in glacier tunnels, laboratory experiments and the Jungfraufirn borehole experiment. Proceedings of the Royal Society of London, Series A, Vol. 219, No. 1139, 1953, p. 477-89.

3. Kerr, F. A. The ice dam and floods of the Talsekwe, British Columbia. Geographical Review, Vol. 24, No. 4, 1934, p. $643-45$.

4. Miller, M. M. Preliminary notes concerning certain glacier structures and glacial lakes on the Juneau Ice Field. American Geographical Society, J.I.R.P. Report No. 6, 1952, p. 49-86.

5. Thorarinsson, S. The ice-dammed lakes of Iceland, with particular reference to their values as indicators of glacier oscillations. Geografiska Annaler, Ârg. 21, Ht. 3-4, 1939, p. $216-42$.

6. Some new aspects of the Grimsvötn problem. Fournal of Glaciology, Vol. 2, No. 14, 1953, p. 267-75. 